\title{
Regional entrepreneurial ecosystems: Technological transformation, digitalisation and the longer term-The automotive and ICT sectors in the UK and Bulgaria
}

Local Economy

202I, Vol. 0(0) I-19

(c) The Author(s) 2021

\section{(c) (i)}

Article reuse guidelines:

sagepub.com/journals-permissions DOI: $10.1177 / 02690942211025776$ journals.sagepub.com/home/lec ๑SAGE

\section{Chiara N Focacci}

Department of Economics, University of Bologna, Italy; IIPP, UCL, London, UK

\section{Vassil Kirov}

Institute of Philosophy \& Sociology, Bulgarian Academy of Sciences, Bulgaria

\begin{abstract}
We investigate how regional entrepreneurial ecosystems have adapted to the information revolution as a techno-economic paradigm since the 1960s. Particularly, we look at how the organisation of firms and labour has changed in the automotive and ICT sectors in, respectively, the UK and Bulgaria. Findings show that, in both countries, it was the degree of cooperation between the local enterprises, research institutions and the government that enabled successful innovation in the regional clusters of the West Midlands and Sofia. The resulting ecosystems allowed, on the one hand, the already mature automotive sector in the UK to survive and, on the other hand, the newly developed ICT sector to be installed successfully in Bulgaria.
\end{abstract}

\section{Keywords}

automotive sector, digitalisation, United Kingdom, Bulgaria, technological revolution, regional business ecosystems

\section{Introduction}

In this article, we investigate how two particular sectors - namely, automotive and ICT - have evolved over time in two particular regions - the English West Midlands and Bulgarian Sofia - in terms of technological change, corporate organisation and work. We refer to Perez' (2002) neo-Schumpeterian vision of five great surges of technical change, 'based on observed regularities in the process of social and economic

\footnotetext{
Corresponding author:

Chiara Natalie Focacci, Department of Economics, University of Bologna, Piazza Scaravilli 2, Bologna 40I26, Italy and IIPP, UCL, II Montague Street, London WCIB 5BP, UK.

Email: chiara.focacci4@unibo.it
} 
assimilation of each new technological revolution'. This vision enables us to examine the different stages of technological revolutions 'from genesis to maturity' by analysing technologies according to their patterns of diffusion, their effect on the organisation of business and institutions, their influence on employment and social life, as well as government's action with respect to their impact on the local economy. ${ }^{1}$

Five technological revolutions followed one another between 1771 and today, introducing the world to machinery, the steam engine, railways, steamships, electricity, cars, computers and the Internet. With the fourth technological revolution that started in 1908 , the mass production of automobiles spread from the US to Europe affecting and changing entire economic systems and, ultimately, our lifestyles. Transport became something tangible for the majority, roads and airports developed, while oil and oil fuels became cheaper. Then, in 1971, when the technologies of mass production were reaching maturity and their markets were saturated, Intel's microprocessor, introduced by inventors Noyce and Moore, opened the way to the information and telecommunications revolution (Berlin, 2003). Computers and software were introduced massively, telecommunications became global and digital, and, in the 1990s, the Internet and e-services such as electronic mail, money transfers and social media, became the norm.

Each technological revolution is necessarily characterised by an irruption phase, when new technologies come in backed up by financial capital in a socio-economic context where the techno-economic paradigm built in the previous revolution is still dominant; a frenzy phase, when the new incoming technologies are 'strongly installed'; and a turning point, requiring institutional changes to fully absorb the new techno-economic paradigm in the economy and society (Perez, 2002). This period of installation, where old and new coexist, is then followed by deployment: namely, a synergy phase, when production capital takes the lead and the new technologies are flourishing, and a maturity phase, when investment opportunities already start to weaken as a potential new technological revolution is about to start (Perez, 2002).

As cyclical waves of innovation irrupt, the stability of local ecosystems - including the existing network of producers, customers and governments committed to the conveyance of products and services - is challenged. Given that the value created by firms crucially depends on the economic coordination of different groups of actors, ${ }^{2}$ the reference to such theory is essential to understand business ecosystems over time. While ours is expected to be a relatively generalisable long-term analysis, we consider it valid to focus on specific territories of the European Union. This makes it possible to look at 'the set of interdependent actors and factors coordinated in such a way that they enable[d] productive entrepreneurship within a particular territory., ${ }^{3}$

Our article aims to fill the gap in the extant literature with respect to a long-term analysis that is, firstly, cross-country - or rather crossregional - and, secondly, cross-sector - according to specific business ecosystems. This longer-term comparative analysis aims to show how technological transformations are always constituted by precise cycles - where unsettled and stable phases take turns - and how an active collaborative behaviour of both firms and governments towards such transformations is crucial for success.

In particular, we look at how the automotive industry and the ICT sector have evolved in, respectively, the English West Midlands and Bulgarian Sofia from 1960 onward. Most importantly, we contrast two peculiar and representative examples of capitalism; namely, the $\mathrm{UK}$, or the 'prime mover of development" 4 and original 'workshop of the world' with respect to industrialisation and the Balkan state of Bulgaria, whose strategic entrepreneurship is more recent and characterised by a Soviet model of planned economy between 1944 and 1989. We focus, on the one hand, on the automotive industry - due to its predominant role in 
the world economy and its core role in the previous mass production revolution. On the other hand, we examine the evolution of the IT sector, at the heart of the Information revolution. This analysis will allow us to comprehend how innovation, including digitalisation - as well as political and economic shocks - affected the business landscape in terms of productivity and corporate structure, and also the distribution and quality of work. In particular, we show that independent of when technological irruptions take place, countries are more likely to achieve success in terms of innovation when they have cooperative local ecosystems characterised by a proactive and synergistic attitude among firms, the government and other institutions - including research centres, proactive groups of entrepreneurs and foreign agents.

The article is structured as follows: the section Framework of Analysis covers the framework of analysis used in this article, while the sections 1960-1973: The Automotive Industry Achieves Its Full Maturity and 19731979: The Automotive Industry Is Hit by the Oil Crisis illustrate the case studies of the West Midlands and Sofia with reference to the evolution of their main business ecosystems. The final section discusses the main findings from a historical and sociological perspective and provides conclusions.

\section{Framework of analysis}

During a technological revolution, regional entrepreneurial ecosystems are initially disrupted, the winners make significant profits; the losers may see their industries and skills destroyed. The automobile and information revolutions both began 'with a group of core industries' in the US, as the new normal way 'of doing things effectively, efficiently and profitably' progressively spread to Europe. ${ }^{5}$ History, however, tells us that this was not a straightforward process. Major booms are followed by crashes and recessions. Events such as wars, demographic transformations or local political crises contribute to impacting business ecosystems. Technological change such as the current digitalisation - however, influences the potential of innovation experienced in an industry to the largest extent. Governments, industries, firms and workers must change and adapt to absorb the new technoeconomic paradigm. The economic agents that constitute the business systems characterised by a network of organisations - such as customers, producers and the government - need to take steps in order to preserve existing value or create new one 'in a sustained way in a particular location. ${ }^{6}$

Analysing the case studies of the UK and Bulgaria in the long term allows us to observe and understand the inception, rise and decline or transformation of certain industries and technologies at the local level. While Ford's famous black car paved the way for a new era (Schorman, 2010) of 'roads, gasoline stations and mechanics', the irruption of a new technoeconomic paradigm by the end of the 20th century would force the automotive industry to re-adapt as electronic chips were introduced in vehicles, equipment became computer controlled and the organisational model developed by the Japanese proved superior. ${ }^{7}$ Similarly, the 4004 single-chip microprocessors of 1971 made it eventually possible for computers to become 'personal' and to spread into cell phones, traffic lights and so on, revolutionising the way we communicate, work and live, while promising a leap in productivity.

Using historical analysis and qualitative sociological research, we argue that technological innovation was not an uncomplicated process in either the automotive or the ICT industry, with different phases following one another from the 1960s to today. Particularly, we aim to investigate, firstly, the role played by political and economic factors at both national and regional levels with respect to the development of ecosystems. Secondly, we are interested in understanding the extent to which different elements of a certain ecosystem, including policymakers and knowledge institutions such as universities and firms interacted in favour of its resilience. 
The focus on specific areas - namely, the West Midlands and Sofia - was based on their being particularly dynamic areas in these particular industries. This focus is justified by the idea that regions are a mirror of a more general reality and can themselves act as 'engines of innovation' by encouraging experimentation. ${ }^{8}$ The latter can, for instance, be achieved through networks between knowledge institutions such as universities and firms inside the region ${ }^{9}$ that contribute to the region's innovativeness. ${ }^{10}$ Both the West Midlands and Sofia are specific geographic concentrations where, in addition to competition, significant cooperation between interconnected producers, suppliers and related institutions ${ }^{11}$ promoted innovation. ${ }^{12}$ This is in line with the concept of regional entrepreneurial system, where interdependent actors within a certain region enhance the development of enterprises also thanks to the specific local socio-economic characteristics of the region. Our long-term analysis allows to shed light firstly on the possibility for surges of technological revolution to occur at different points in time depending on the country and secondly on the possibility for countries to converge from an innovation viewpoint. Particularly, we argue that this is due to the introduction of cooperative networks between firms, the government and knowledge institutes in both the British West Midlands and Bulgarian Sofia.

While entrepreneurial theory is crucial to understand why certain industrial clusters evolve and others disappear due to their obsolescence, Perez' (2002) theory helps us convey the argument that firms alone are not able to successfully achieve the Golden Age that a technological revolution tries to give rise to. On the contrary, during the unfolding of a technological revolution, the co-responsibilisation of economic and institutional agents is crucial to address economic cycles of recessions, international competition and new challenges, such as environmental sustainability. In the next section, we illustrate how the automotive and ICT sectors have transformed and incorporated the inevitable changes brought by technological disruptions in the UK and Bulgaria and conclude that collaborations between different economic agents - from business ecosystems to government - contribute to make success significantly more likely.

\section{The UK and Bulgaria}

In this section, we investigate the development of one of the most significant clusters of the fourth technological revolution in the UK region of the West Midlands - the automotive industry -, as well as the digital protagonist of the current fifth technological revolution - the ICT sector - , in Sofia, Bulgaria. Particularly, we look at how these two sectors have transformed between 1960 and today.

\section{The automotive industry in the West Midlands}

Due to their expertise in the sector, their role as an international exporter of vehicles, as well as the significant presence of connected business clusters in the territory, one might assume that the West Midlands, preceding the North West and North East, implemented the new technologies and new knowledge, such as IT, ${ }^{13}$ effortlessly. However, we show that the process of innovation, and later digitalisation, in the automotive sector was not an unchallenging one - especially with the consequences of the 1973 oil crisis.

The age of cars and mass production (1908) and the age of ICT and digitalisation (1971) both started in the US. As a latecomer, the UK benefitted from the overlap of these two technological waves. In this section, we show how the automotive sector's survival and development in the West Midlands was possible due to the synergistic set of actions by the government, the local firms and the workers. This allowed the industry to reach maturity and remain a potential source of attraction for investors despite major economic and political crises and global competition. As the ICT 
revolution expanded in all sectors, the latest effort by the automotive industry was to become digitalised. The collaborative nature of the West Midlands' business ecosystems contributed to achieve this.

1960-1973: The automotive industry achieves its full maturity. Herbert Austin inaugurated the West Midlands' automotive destiny as early as 1900, when he built the first all-British fourwheel car. By 1929, Austin's motor company in Birmingham was still one of the biggest producers in the UK, and at the dawn of WW2, Standard, Rootes and Vauxhall had joined the race making the region's production of cars an iconic case for the country.

In the mid-1950s the automotive industry was at its productivity peak in the West Midlands, with production capital 'at the helm,14 and $64 \%$ of the workforce in Coventry based on engineering and vehicles. ${ }^{15}$ The new technoeconomic paradigm characterised by oil and mass production, which irrupted in 1908 in the US, had been successfully installed in the West Midlands, which were now a high-employment high-wage sub-economy. ${ }^{16}$ In 1960 , however, the automotive industry reached what Perez (2002) calls maturity in the region and began declining. The production of vehicles produced in the UK slowed down and went from $26.9 \%$ in 1963 to merely $14.2 \%$ in 1969 as a share of Europe and Japan. Foreign investors disappeared, profits decreased, and several firms merged to survive - automobile manufacturer Rootes, for instance, was incorporated to Chrysler from mid-1964. ${ }^{17}$

The very nature of maturity barely resulted in minor innovations in this period. Product engineers introduced the electronic fuel injection system to eliminate engine inefficiencies in 1966, while one year later seatbelts were compulsorily applied in all cars produced in the country, together with electric windows and intermittent windshield wipers. ${ }^{18}$ Notwithstanding, there were two groups that found innovative ways to overcome the limits of maturity. Firstly, technological investments were made by the more specialised automotive manufacturers such as Jaguar and Rolls Royce, which exploited this critical decade to reinvest in professionals such as design engineers to strengthen their niche in the luxury economy. That market was growing in the 'winner take all' economy that was emerging in the advanced countries. Secondly, larger firms with high technology, such as the supplier of steel forgings for the automotive sector GKN Forgings, located in Bromsgrove, became popular for their hands-on management style ${ }^{19}$ in favour of investments in local engineering and heavy R\&D.

With respect to the labour force, workers could not be paid according to the amount produced due to the high levels of inactivity in the automotive industry. In the West Midlands, this led to the Coventry Toolroom Agreement. With the introduction of Measured Day Work - calculated using industrial engineering techniques - , employees were paid a fixed wage in exchange for agreed daily output and performance levels. ${ }^{20}$ During this period, the automotive industry began to progressively abandon the highly labour-intensive mass production methods, and to shed technicians and semi-skilled workers. The occupational effect of maturity was somehow cushioned by the government's issuance of new industrial certificates conditional on relocation in highunemployment areas. Yet, due to the high concentration of plants in Longbridge, Birmingham and Coventry, it was still possible to provide work to the people in the West Midlands - in the late 1960s - 'there were [still] 8 jobs for every Birmingham schoolleaver. ${ }^{, 21}$ However, the number of individuals employed in the automotive industry in the country had dropped by more than 50,000 at the end of the decade.

Between 1962 and 1964, the Conservatives attempted to stimulate demand by reducing the Purchase Tax - levied on luxury goods, including cars - following which, demand annually grew by $17 \%{ }^{22}$ This short-term measure was followed by the more significant establishment of the Ministry of Technology under 
the Labour party in 1964; boardrooms were now filled with scientists and technologists. ${ }^{23}$ These earlier efforts on the part of the UK government, however, were not sufficient to revive the automotive industry. As a result of unresolved difficulties, in 1968 the government decided to merge the Leyland-Triumph-Rover car manufacturers group and British Motor. The resulting merged company, British Leyland Motor Corporation, became the largest car manufacturer in the UK and reached an output of 800,000 units $^{24}$ in 1970. At this point in time, the West Midlands could only count on their own regional and collaborative ecosystem for the endurance of the automotive industry.

1973-1979: The automotive industry is hit by the oil crisis. At the beginning of the 1970s, the market was saturated, firms did not show any productivity increases, while profits were not sufficient to respond to labour's demands. Following the accession of the UK into the European Economic Community in 1972 under the Conservatives, on December 1973 the price of gasoline skyrocketed due to the OPEC oil crisis, which caught the automotive industry unawares. By 1975, the British Leyland Motor Corporation had debts amounting to $£ 220$ million, with its UK market share falling from $40 \%$ at its peak to $15 \%$ at the end of the decade. ${ }^{25}$ Following global recession, the automotive sector had officially entered its deployment stage.

In terms of innovation, this was a period marked by safety improvements - including the Anti-Lock Braking System and airbags - and emissions changes in production strategies such as catalytic converters. With the oil crisis of 1973, however, it was manufacturers' production strategies that mostly needed to change. By including quality operations technicians and engineers in their teams, manufacturers started using materials such as aluminium and plastic and smaller engines, which made cars lighter and more efficient in terms of petrol usage per mile. The car manufacturer Rover also invested in restructuring technologies and was able to launch a new type of vehicle, the off-road segment. ${ }^{26}$ As the automotive industry was still ailing, manufacturers did their best to innovate strategically, if not technologically. Indeed, as financial capital was moving away from the car industry, ICT technologies were finally irrupting everywhere. $^{27}$

Understandably, the energy crisis also had effects on the working population. In 1975, the West Midlands employed a total of 203,000 individuals in the car industry, including 99,900 in the car assembly plants and 103,400 in component suppliers. ${ }^{28}$ Compared to 1972 , the Talbot car group in Coventry, for instance, had reduced employment from 22,000 to merely 7000 by $1981 .^{29}$ In parallel, suppliers of largescale financing favoured the US subsidiaries in the region. ${ }^{30}$ Owned by General Motors, the car manufacturer Vauxhall, was able to introduce the typically American multi-station transfer equipment - which exploited sub-assembly lines to create specific components and stock them for use. ${ }^{31}$ The already mature automotive industry was struggling, with each firm trying to survive - some successfully, some not.

Both the Conservatives (Edward Heath) and the Labour party (Harold Wilson and James Callaghan) party offered a $£ 2.4$ million regional aid to the West Midlands between 1972 and $1979 .{ }^{32}$ But following such intervention, only 7500 jobs, $5 \%$ of the total, were created in the region. ${ }^{33}$ As history confirms, money alone is not sufficient a means to solve systemic issues, even more so when it comes to an already fragile industry. The general dissatisfaction towards the government, also reflected in the Winter of Discontent of 1978-1979, resulted in the fall of Labour Prime Minister James Callaghan and the election of Thatcher.

1979-1990: Thatcher and the Japanisation of the automotive industry. 1979 marked the beginning of 18 years of Conservative government, monetary policies and the privatisation of numerous companies - including British Airways, Telecom, Steel and Gas. The high interest rates 
set by Thatcher, as well as the abolition of exchange controls, and the increase of the VAT to $15 \%$ in 1979 strongly hit the automotive industry, but they could not count on government subsidies - quoting her, 'there [was] no such thing as public money; there [was] only taxpayers' money'. In parallel, stagflation became unbearable; the inflation rate reached $18 \%$ in 1980 , while the unemployment rate reached $11.5 \%$ in 1983 . Thatcher's ${ }^{34}$ 'sweeping programme of privatisation' aimed 'to delay [British Leyland's] death by finding a suitable replacement in the right condition', 35 but this cost the job, social unrest and poverty of many.

The fact that the ICT surge irrupted creating a new techno-economic paradigm when the automotive sector had already reached maturity (Perez, 2002) meant that a new type of organisation was required to survive stagflation. Firms started adopting the zero-defects 'Justin-Time' (JIT) principle developed by Ohno for Toyota and based on 'eliminating waste. ${ }^{36}$ In Birmingham, the automotive components plant of Lucas Electrical introduced a system of cells with defined modules of production for each worker. ${ }^{37}$ In Longbridge, the car manufacturer Rover Group implemented a minimum inventory programme, while Jaguar reorganised its sites 'into cellular systems of control' 38 that led to an increased pace in innovation and quality. ${ }^{39}$ In parallel, JIT gave firms the confidence to introduce computer-aided design and manufacturing, making the process of designing vehicles and combining tools more efficient for automotive designers and engineers. As a result, in 1985 the expenditure in R\&D for manufacturing - which included the automotive sector - surpassed $84 \%$ of all R\&D expenditure in the UK. ${ }^{40}$

Eventually, the concept of work also changed. The Iron Lady's decade unfolded with dramatic stagflation ${ }^{41}$ leaving 3 million people out of work in 1983 and wages reduced, while the 'Just-in-Time' principle created a highquality and high-intensity 'technical division' of labour. $^{42}$ The new working practices in the automotive industry required fewer but more skilled workers - as observed in the Stoke plant of Coventry, for instance ${ }^{43}$ - backed up by the anti-union legislation approved by the promarket Conservative government. ${ }^{44}$ In 1980 , for instance, engineering service provider Coventry Hood and Seating cut 120 positions, the supplier of tyres Coventry Radials 230 and Renolds $900 .{ }^{45}$ Workers now had to 'move between several different machines in conjunction with work moving through the factory by means of manual (single-unit) transfer, conveyors, chutes and pick-and-place robots. ${ }^{, 46}$

Evidently, the 'Just-in-Time' principle changed relations also with suppliers. Between 1982 and 1986, the motor manufacturer Austin Rover reduced its suppliers from 1200 to 700 ; Ford UK limited the number of favourite suppliers from 2500 to 900; and so did Jaguar and Nissan. ${ }^{47}$ Having specialised first-tier suppliers directly involved with them ensured just in time delivery of parts. The application of Japanese principles to car production in the UK became an incentive to create the first European integrated systems of suppliers. As manufacturers invested in R\&D and training for their suppliers and transferred 'appropriate [knowledge] and practice' to them, what Bessant et al. (2003) refer to as 'inter-firm learning' started to emerge.

The strict corporate governance allowed by Thatcher between 1979 and 1990 was catastrophic for the labour force but liberating for enterprises. On the one hand, Thatcher saw regional policy as 'a zero-sum game in which one region could benefit only at the expense of other regions, ${ }^{48}$ so that programmes to create jobs in Assisted Areas stopped and the North-South divide became more evident. ${ }^{49}$ On the other hand, the interdependence between investment in machineries and innovation became more evident at the end of her political leadership, especially in the West Midlands ${ }^{50}$ - one eight of the workers employed in Stoke-on-Trent's tyre giant Michelin, for instance, was specialised in engineering for microprocessors at this time. ${ }^{51}$ Similarly, there was strong collaboration between producers of cars and electrical machinery and communications equipment industries technology. ${ }^{52}$ 
The 2 I st century: The automotive industry achieves full digitalisation. The 21 st century opened with a bang. The automotive sector had already survived the oil crisis, stagflation and Japanisation. The crowning moment, however, was reached with the financial crisis of 2008, which represented the new dramatic incentive to innovate according to a new ICT Golden Age (Perez, 2019) in order to remain afloat and, ultimately, embark on greener routes.

In the prospect of innovation, the advancement in technology and the investments in new disciplines such as mechatronics, allowed car companies to introduce GPS and Bluetooth systems, as well as driver-assist technologies such as automatic parking and self-driving cars. With respect to the West Midlands, Jaguar Land Rover started an Analytics Revolution project with digital scientists 'to help businesses build effective analytics and assess business cases. ${ }^{, 53}$ Similarly, Warwick Analytics gave life to the Sigma Guardian system, exploiting algorithms to identify and resolve faults in vehicles 'as they occur', saving up to $20 \%$ of the costs. ${ }^{54}$ On the supply side, the driveline technologies' supplier GKN launched its Radio Frequency Identification system in 2015 to collect data from heat treatment, welding and assembly and understand faults in both production and service.

In parallel, the green agenda began to take force across the economy, with more and more firms switching to low-carbon vehicles ${ }^{55}$ in the 21 st century. The birth of Tesla in 2003 worked as a fundamental wake-up call for manufacturers in that it announced the obvious future of electric cars and hydro-motors in the market. In the West Midlands, for instance, General Motors set a new production metrics based on 'energy use, water use, greenhouse gas emissions, recycled waste and non-recycled waste. ${ }^{56}$ The innovation process forced on manufacturers by the 2008 economic crisis inadvertently set off a new and superior purpose for the automotive industry.

With respect to the labour force, in 2002 the West Midlands were still considered the heart of the UK's automotive industry, with 330,450 individuals employed in transport technologies and the largest concentration of companies in the country - including MG Rover in Birmingham, Peugeot and Jaguar in Coventry and Land Rover in Solihull. ${ }^{57}$ In parallel, the collective learning typical of the West Midlands contributed to saving $10,000-12,000$ jobs between 2000 and $2005,{ }^{58}$ as well as creating new ones. Between 2009 and 2012, Jaguar Land Rover created 6000 new jobs, many related to mechatronics and low-carbon vehicle technologies, while the number of people employed in the automotive sector was still more than 36,500 in 2010 . $^{59}$

The technological revolution that gave origin to the mass production of cars was now in its deployment period, in parallel with the gestation of the techno-economic paradigm brought by the new ICT revolution (Perez, 2002). In line with this, research institutes played an irreplaceable part in supporting the automotive industry in its progressive adaptation to the digital world. In this regard, $£ 30$ million were invested by the University of Warwick, supported by the regional 'Advantage West Midlands' agency (RDA), coordinated with the national Technology Strategy Board, for high-tech projects such as 'advanced materials, joining and assembly technologies, electronics and hybrid systems. ${ }^{60}$ The agency claims to have led to the creation of 10,000 new businesses and the creation or safeguarding of 140,000 jobs' between 2005 and 2008. ${ }^{61}$

From a political perspective, the Labour government's commitment proved to be vital to the survival of the automotive industry. First, the 2009-2010 'scrappage incentive scheme' allowed consumers to scrap their old cars for a $£ 2000$ discount on the purchase of a new car. As a result, car sales increased by $10 \%{ }^{62}$ Second, West Midlands were supported generously in favour of innovation. An initial $£ 7.13$ million regional fund for investment in new technologies was followed by an Innovation Voucher Scheme, which offered $£ 3000$ 
'to purchase research support from any of the 13 regional universities', as well as an Innovation Networks system, which provided $£ 10,000$ grants for collaborations between small-medium firms, ${ }^{63}$ allowing them to create technologically innovative products. At present, the reforming stimulus in favour of the automotive sector brought by the Conservatives has been the 2018 Road to ZeroEmissions Strategy. Prior to this, the West Midlands had already invested $£ 9.5 \mathrm{~m}$ in a Low-Carbon Vehicle Technology Project, together with Jaguar Land Rover, Tata Motors, Zytek, Ricardo, MIRA and WMG at the University of Warwick and Coventry University. ${ }^{64}$ As we have seen then, the automotive sector has undergone a series of transformations in the last 60 years. Firms, workers, universities, high-tech companies and the government played a fundamental role to bring about change in the automotive industry whilst political and economic shocks unfolded abruptly. All agents active in the economic system surrounding the automotive industry intervened precisely when it was their interest to ensure, firstly, the survival of mature businesses and organisational practices and, secondly, their exhaustive transformation in favour of more digitised and efficient methods. Such reactive participation was not exclusively reflected in the progressive improvement in the labour force's skills, but also in the cohesive inception of an integrated system of manufacturers and suppliers - of both knowledge and materials. Notwithstanding, the recently learned beneficial functions of the collaborative relations for the "commonality of interests" that has become typical of the automotive industry, and evident for the West Midlands, is likely to become much more difficult in the Brexit future.

\section{The IT sector in Sofia}

In the context of the poorest and less technologically developed EU country, Bulgaria's capital Sofia is an interesting case because of the spectacular development of knowledgeintensive ICT sector experienced during the last decades both in the conditions of socialist state economy and in the post-communist dependent capitalism. ${ }^{65}$ With a population of 1.3 million (2018), this NUTS 3 region had one of the lowest GDP (PPS) per capita for a capital region in the EU, but about 2.2-2.3 times higher than the average for the country.

The decade of the 1960s: The birth of the ICT in the context of the industrial modernisation during the socialist planned economy. The development of the ICT ecosystem in Bulgaria started in the $1960 \mathrm{~s}$, when the country was still a planned economy of Soviet-type, belonging to the Council for Mutual Economic Assistance (CMEA) - the economic alliance of the former socialist countries. The development of Bulgarian electronics was part of the general industrialisation process that started in the country in the early 1950 s following the Soviet model. ${ }^{66}$ At that time, Bulgaria was lagging behind even among Eastern European countries in terms of technological development, while its newly built heavy industry, dominated by chemicals, electrical and motor trucks, was not known for its quality. ${ }^{67}$

About two decades later, at the end of the 1970s and the 1980s, Bulgaria, alongside East Germany, had become the largest producer of hardware and software in CMEA, ${ }^{68}$ as the result of the proactive industrial policy implemented in the field and explained below. After the launch of the first Bulgarian computer 'Vitosha' in 1960s, ${ }^{69}$ the state-led ICT sector developed within the framework of public research institutes and the newly launched large state enterprises in the field. The fact that ICT developed in a less advanced country makes it interesting to understand the reasons behind. Building on Schumpeter (1976), Tchalakov (2001) argues that the category of socialist entrepreneurs originates from a very narrow segment of the population, the so called nomenclatura, in possession of significant resources and able to convince the communist 
leaders. A key figure for the Bulgarian ICT ecosystem that illustrates the concept of socialist entrepreneur, between 1949 and 1974, was Ivan Popov, ${ }^{70}$ Minister of Machine Building and Communist Party high official, who led the development of the ICT industry in Bulgaria. After his pre-War career as a scholar in France, independent entrepreneur in Bulgaria and then manager of the AEG plant in Hungary for 10 years, in 1949 Popov returned to communist Bulgaria and was appointed as executive director of the newly nationalised electro-technical plan Elprom. He then became professor at the Technical University in Sofia, as well as served in the DDR's (former Eastern Germany) R\&D unit for three years. In 1961, he came back to Bulgaria and was appointed as State Committee for Science and Technical Progress. When back, Popov presented a plan to the members of Politburo with regards to Bulgaria's race for computer technology. The plan included '(1) establishing close relationships with Western producers of aimed computer devices, reverse engineering these devices, ${ }^{71}$ (2) building innovative industrial facilities in an unknown scale, and idea which was also borrowed from the West and (3) providing special protected organisational environment for the development of the new industry both a national and international (CMEA) level' (Tchalakov and Burton, 2001: 23). In 1969, the Intergovernmental Commission for Cooperation of Socialist Countries in the Field of Computer Technology (IGCCT) was established in Moscow. In this institution, Popov successfully lobbied for the development of key components for computer production in Bulgaria. ${ }^{72}$ As planned, the development of the ecosystem took place also on the basis of strong collaboration with Western companies, including Fujitsu from Japan, as well companies from France and Germany. In this way, Bulgaria was able to successfully specialise in the production of key ICT items. The third pillar was to build the needed industrial facilities. In this vein, the 1967-established state enterprise IZOT Co, with headquarters based in Sofia, aimed to accelerate the development of the electronic industry, following the model of East Germany based on highly integrated corporations. IZOT included production facilities and $R \& D$ structures within the country but the main units were based in Sofia. ${ }^{73}$ At the end of the 1960s, the phase of irruption was implemented. But differently from the Western world, the new technologies had not been backed by the financial capital, but by the Communist party elite itself.

As a result, the installation phase developed during the 1970s and early 1980s. The simultaneous construction of seven plants for electronic equipment began in 1969 under the direct guidance of Ivan Popov. The ICT also included the previously constructed plants for semiconductors (Botevgrad) and computers (Sofia), as well as the large state-owned companies created by the Communist state authorities and specialised in the production of calculators, personal computers and storage devices - such as the 'Mikroprozessorni sistemi' producing computers and the 'Elektronni elementi' producing electronic appliances, telephones and computer parts.

The 1970s and 1980s: Consolidation of the ecosystem and leading role in the socialist world. In the 1970s and 1980s, Bulgaria was already producing storage devices, microprocessors and all the necessary equipment for computers: the ecosystem had officially entered the frenzy phase of the technological revolution. According to Boyanov (2014), more than 30 factories were operating in the field of computer technology by the 1980s. Just before the fall of the communist regime in 1989, the electronics and telecommunications sectors accounted for $25 \%$ of industrial production in Bulgaria employing about 130,000 people, including 8000 highly qualified engineers. ${ }^{74}$ However, about $95 \%$ of its production was sold in the former USSR, illustrating the industry's dangerous economic dependence on a single large country. In addition, the industry was 
highly dependent on reverse engineering and follow-up of the leading Western technologies. With respect to the companies and $\mathrm{R} \& \mathrm{D}$ structures, these were all state-owned, dispersed over the territory of the country, but often with headquarters and research departments in the capital Sofia. In addition, in Sofia were located the central administrations ensuring the governance of the ecosystem (e.g. the State Planning Committee, the Ministry of electronics and electrotechnics), as well as the main technical universities - such as Technical University. ${ }^{75}$ In the 1970 s and 1980 s, Bulgaria was considered an early integrator of ICT, as well as of other sectors, ${ }^{76}$ with much of the technological development being based on cooperation with leading worldwide producers and local investment in R\&D. The business ecosystem also included a number of vocational training schools, technical universities, as well research labs within the Bulgarian Academy of Sciences. This development led to the start of the maturity phase in the late 1980s.

1989-2020: From the dramatic transition to the spectacular growth. After the political changes of 1989, the ICT industry in Bulgaria underwent a profound change. At the beginning of the 1990s, all the large state-owned enterprises in the sector were dismantled in the process of de-monopolisation, ${ }^{77}$ with $\mathrm{R} \& \mathrm{D}$ centres closed and most companies losing their market share. In the context of a shock therapy, in 1991 prices have been liberalised and free market relations introduced. ${ }^{78}$ The loss of the former secure CMEA markets, the dismantled corporate structures and the lack of market economy know-how led to the quick collapse of the hardware sector. But while hardware production had all but disappeared, in the 1990s an emerging private sector was already developing around individuals and teams of managers and programmers from the formerly state-owned companies who started private businesses, ${ }^{79}$ mainly in software production. During the 1990s, the state abdicated from the economy but the ecosystem could still count on the firms, the technical universities and some public research facilities.

By the late 1990s and the beginning of the new decade, many of these software companies had become well integrated in the global value chains (GVCs), ${ }^{80}$ initially as sub-contractors combining good technical skills with low labour costs. Gradually, several of those companies were able to move upward in their respective value chains, to more complex tasks and high-value-added projects. ${ }^{81}$ The country could not become a technology champion but successfully developed a niche production of software as early as 2000 , becoming the 25 th fastest growing ICT market in the world between 2003 and 2007 (ARC Fund, 2019: 102). It was already in this period that Bulgaria could count on some of the leaders in the ICT regional entrepreneurial system; namely, the software producer Telerik AD, Sirma Group and their company Ontotext in the semantic technologies or Chaos Group in the 3D visualisation. While in the pre-1989 period, part of the production facilities had been distributed in different regions of the country; after 1989, the ICT was mainly concentrated in Sofia. This economic transformation was to a greater extent shaped by the significant increase in the share of knowledge-based services in the city of Sofia since 1990 onwards.

This process was boosted after Bulgaria joined the European Union in 2007. First of all, the EU membership heralded the return of the State in the economy, at least in the terms of strategic planning. The EU membership implied the development of strategies such as the one for smart specialisation. Not surprisingly, in the 'Innovation strategy for smart specialisation of the Republic of Bulgaria 2014-2020 (IS3)' report, ICT is identified as one of the four thematic priorities for the country. While the country has set ambitious objectives so as to move from the group of 'modest innovators' to that of 'moderate innovators' (according to the terminology of the European Innovation Scoreboard), the plan provided the public authorities with a fundamental direction. As a 
result, in 2018, Sofia became the first Bulgarian municipality to adopt and implement its Strategy for Smart Specialisation: in line with the national priorities, the capital city set informatics/ICT technologies and the creative and recreational industries as priority sectors. As of 2020, the city has also appointed a vice-mayor in charge of the digital transformation. While it is too early to evaluate this strategy, it is evident that the municipality has already started to proactively support the ICT ecosystem.

Secondly, the EU membership granted access to different European funding mechanisms. ${ }^{82}$ The ICT sector developed without external support until the late 2000s, but the existence of EU funds has been crucial for its further development. In parallel to the direct support of ICT companies, the European Investment Fund has allocated 21 million euros through the JEREMIE programme to the accelerator, early-stage fund Eleven and the seed fund LAUNCHub. In recent years, Sofia Tech Park, the first science-and-technology park in Bulgaria, was created as a platform for exchanging knowledge and ideas among academia, businesses, government and society with EU subsidies for $€ 34$ million.

The investment of EU funds has been complemented by private capital. Alongside the two funds, a community of angel investors has started investing in idea-only or early-stage companies. Incubators and pre-accelerator programmes such as StartItSmart, nine Academy and Founder Institute have started to provide knowledge and skillsets to new entrepreneurs. The formation and expansion of the venture capital community in Sofia have further supported more mature start-ups and companies in their growth stage (e.g. NEVEQ), as well as university curricula.

Not surprisingly, the developments that occurred after 2007 were significantly favourable for the ecosystem. The existence of foreign and local investment, the greater participation and upgrade of Bulgarian companies in the GVC and the use of EU funds contributed to the increase in its international competitiveness. The
EU membership also became a positive signal and guarantee for foreign investors to take more responsibilities in the ecosystem. Thus, one can argue that it is precisely after 2007 that what Perez (2002) calls 'turning point', requiring institutional changes to fully absorb the new techno-economic paradigm in the economy and society, took place.

It is not surprising, then, that data on employment by economic activity indicate how, over the last several years, Sofia's economy has undergone restructuring due to rapid growth in the IT and related business outsourcing industries. Following this robust development, the country's IT sector, concentrated in Sofia, in 2018 was proclaimed the best performing industry in Bulgaria. A decade's worth of $600 \%$ increased income since the European Union accession in 2007 made it the fastest country's growing sector. The past 10 years have seen the local ICT sector experience a transition from outsourcing, based on low-cost labour and low added value, to R\&D-intensive and high-valueadded products and services, including for the global automotive producers. ${ }^{83}$ For this period, Bulgaria has confirmed its position as a destination for the development of R\&D-intensive and innovative technologies - not only in software but in hardware as well. ${ }^{84}$ This trend is even more clearly visible in the field of software product development, in which ICT multinationals have been establishing $R \& D$ centres since the early 2000s, mainly through buying out their longstanding Bulgarian subcontractors (e.g. VMWare Bulgaria, Software AG, SAP, Devexperts, Progress, Bosch Software Innovation Sofia, IDT Bulgaria and Leanplum Bulgaria).

In parallel, several authentic Bulgarian companies claim to rank among innovative global leaders, albeit within 'narrower' specialised market niches - such as software producer Chaos Software, the global leader in enterprise knowledge graph technology and semantic database engines Ontotext; the software producer Interconsult Bulgaria, the producer of mobile and business apps Mobile 
Systems; Software Group Bulgaria, specialised in digitalisation and integration solutions for institutions that provide financial services; and Sirma Medical Systems, delivering software applications and smart data management for healthcare. Bulgarian companies in this sector have now begun providing products and services to end-clients instead of being involved only in sub-contractor networks. Together with several dozen large companies, there are fastgrowing SMEs in numerous segments from Fintech, Cleantech, and gaming to EdTech and entertainment.

Such successful developments in the sector have made it more attractive to 'budding' entrepreneurs. ${ }^{85}$ About $30 \%$ of the companies operating in 2018 were founded after 2014. Almost three-fourths of these new businesses are located in the 'Information technology activities' sector, which includes programming and execution of consulting services in connection with computer maintenance and computer systems. A recent survey on Bulgarian ICT start-ups has also acknowledged their overconcentration in the capital city illustrating the attractiveness of the Bulgarian capital for the start of new businesses within this ecosystem.

The bulk of the ICT sector is, thus, concentrated in the Bulgarian capital (accounting for $87 \%$ of revenue, $80 \%$ of employment and $91 \%$ of added value for the whole sector in 2018). At present, 14\% of Sofia's exports are produced by the IT sector, itself employing about 50,000 people (in 2018), who are paid 34 times more than average wages in the city.

An important segment of the ICT has become the outsourcing industry, which was hardly known in Bulgaria amid the 2000s. The movement of operations among companies active in the outsourcing of business services to Bulgaria was partially driven by the available skills, relatively good infrastructure and lower wage costs in the country. In some cases, activities were relocated from former sites in Western or Central Europe. By 2016, the value added of the outsourcing sector in Sofia had reached a record of 2.2 billion Bulgarian leva (or $€ 1.1$ billion), about $50 \%$ above its 2011 level. Thus, the outsourcing industry has already contributed $10 \%$ in added value to the capital's economy. At present, there are 60,000 employees working in business process or information technology outsourcing, mainly located in Sofia. 4.8\% of Bulgaria's GDP is generated by this sector, making Bulgaria the third most attractive outsourcing location in the world according to the 2015 Business Process Outsourcing (BPO) \& Shared Service Location Index by the global consultancy group Cushman \& Wakefield.

In the last decades, the talent and skill providers have majorly contributed to the IT ecosystem. Sofia, for instance, benefits from the concentration of educational institutions providing skills for the ecosystem. At present, 23 universities with more than 100,000 students (including 42,000 in STEM) and 63 research centres are located in the capital. Furthermore, several private educational initiatives have been launched recently in order to fill the skills gaps. Specific examples of those 'academies' are the Software University, called SoftUni, and the Telerik Academy - both launched by founders of successful IT companies. Since its establishment in 2014, about 5500 students graduated from the 1-year training curricula and $92 \%$ of them have started work in local IT companies. Established as an alternative to the standard universities, the private IT academies focus on the practical aspects of the software development, thought by practitioners from leading companies.

The development of the ICT entrepreneurial system in Sofia has enabled high-road development, pushed by the digital transformation and the EU membership. In the context of drastic economic and societal changes, the Bulgarian ICT sector succeeded in transforming itself in the early post-socialist years and integrating with the GVC, firstly, as a lowwage, low value-added sub-contractor, but lately as a high-value-added supplier of specialised software and IT solutions. Most recently, this development has been led by multinationals 
with local R\&D centres on the one hand, and highly specialised local companies on the other. Simultaneously, the ecosystem has benefitted from the path-dependent developments, availability of skills and improved access to finance, especially following Bulgaria's EU accession, the state support and long-term strategy planning. However, the strategic positioning of the city with regards to ICT development has been recent, and the mobilisation of EU/national support instruments has still not proven sufficient to overcome policy gaps, in terms of skills provision or infrastructure, enabling private actors such as the academies to do their part. The pathdependency and integration with the GVC have both played positive roles in keeping human potential in the region of Sofia and attracting talent from the countryside. This indicates that the ecosystem is still in the synergy phase of the technology deployment. Still, even given that digitalisation's effects have been socially inclusive in general, it is difficult to evaluate the potential spillover effects on other business ecosystems or other regions in the country. Finally, the ICT ecosystem seems to be beyond the reach of the 'captured state" 86 because ICT and BPO businesses stand independently from organised mafia-type groups and the so called 'captured' state. This is due to the complex and often transnational character of IT activities, not easily understood by various oligarchic circles and based on the prevalence of intangible assets such as human capital.

In sum, the development of the ICT system in the city of Sofia illustrates the deployment of the new technologies of the Fifth Industrial Revolution in the context of emerging and peripheral market economy and their mainly positive effects on employment and economic development. The development of the post1989 business ecosystem, however, could not be understood without considering the pathdependency from the pre-1989 period and the existence of multiple elements of the business system that have been transformed afterwards such as the qualified software and hardware engineers.

\section{Discussion}

Building up on Perez' (2002) neo-Schumpeterian vision, in this analysis we illustrated how each new technological revolution entails consequences in both the organisation of work and production in firms, as well as requires proactive intervention on behalf of the government. This is particularly true when different techno-economic paradigms coexist or overlap in their development.

The case studies relative to the automotive industry and the ICT sector show how each ecosystem undergoes phases of irruption, stabilisation and maturity and that the synergistic actions of institutions and individuals is essential for the economic and social adaptation to newly introduced technical paradigms. As we have illustrated in the previous sections, in the long term the two regional entrepreneurial ecosystems of the English West Midlands and the Bulgarian Sofia experienced partial or complete restructuring to survive technological and organisational change. Particularly, the proactive and cooperative response to factors such as rapid globalisation and internationalisation of capital on behalf of firms, the government and agents such as universities allowed for the survival and development of the automotive and ICT sectors. In the UK, the latter was possible also thanks to the intervention by both the government and the local authorities, as well as the strong collaborations between firms and research institutions - in line with Stam and Spigel's (2016) argument that innovation proliferates in specific geographical clusters. In Bulgaria, during the pre-1989 period, the development of the ecosystem was completely dependent on state intervention, encouraged by the activity of the so-called 'socialist entrepreneurs. After 1989, it experienced firstly a state of laissez-faire in order to adapt and survive, leading to major disruption while it was able to further develop, following 
2007, thanks to the mobilised public and EU support.

Technological revolutions and new economic paradigms allow the survival of industries only insofar they are prepared to adopt the new quickly. Most of the time, strong collaboration and government support are necessary to achieve this goal. This article showed that in both the cases of the mature automotive sector in the developed UK and of the freshly introduced ICT sector in developing Bulgaria, technologies radically changed the way in which entrepreneurial ecosystems worked. While decisive collaboration between agents such as firms, research institutions and the government was crucial in the UK to make creative destruction purposeful, joint effort encouraged by local entrepreneurs in Bulgaria became pivotal to adapt to a technological system afresh.

The automotive and ICT sectors developed in two very different countries: namely, the British 'workshop of the world' and the Bulgarian new economy. The long-term perspective used in this analysis, however, shows that in both cases, the solution to complex industrial realities was always the compromise between state and private intervention. In other words, the West Midlands and Sofia represent the key economic clusters of their countries due to the open entrepreneurial system they assured over time by allowing collaborations between firms and proactive entrepreneurs, research institutes and reactive governments. As the result of the synergistic behaviour observed in these areas, the entrepreneurial ecosystems of the West Midlands and Sofia were able to overcome the educational and organisational gaps caused by external political and economic events by re-inventing their products, ameliorating their techniques of production, supply and management, and reconsidering the role of their labour force.

Innovation processes such as digitalisation do not occur automatically. They are determined by the actions of specific economic agents and the relationships between them.
The crises of 1973 and 2008 were addressed by reskilling workers and creating an enviable system of integration between firms, at both local and international levels. Policymakers of today must deal, on the one hand, with the climate catastrophe, and on the other hand, with the COVID-19 pandemic. Repercussions can be dramatic if actions are taken in view of short-term results. This article shows that exploring regional entrepreneurial systems is key to understand how to reproduce 'engines of innovation' large scale, ${ }^{86}$ but that success in doing so significantly depends on the range and power of actors entitled to act within the political and geographical context of reference.

\section{Declaration of conflicting interests}

The author(s) declared no potential conflicts of interest with respect to the research, authorship, and/or publication of this article.

\section{Funding}

The author(s) disclosed receipt of the following financial support for the research, authorship, and/or publication of this article: The authors are indebted to Carlota Perez, Ulrich Jürgens, Ivan Tchalakov, Pepka Boyadjieva, Joshua Ryan-Collins, Steven Dhondt and Peter Oeji for their comments and feedback on an earlier version of this article. This research was undertaken within the BEYOND4.0 project, which has received funding from the European Union's Horizon 2020 research and innovation programme under grant agreement No. 822296.

\section{ORCID iD}

Chiara N Focacci (D) https://orcid.org/0000-00019583-9180

\section{Notes}

1. See Perez (2017).

2. See Williamson and De Meyer (2012).

3. See Stam and Spigel (2016), Spigel et al. (2020).

4. See Griffin (2010).

5. See Perez (2002). 
6. Economist Intelligence Unit (2014).

7. See Perez (2002).

8. See Uyarra and Flanagan (2016).

9. See Acs et al. (2017).

10. See Cooke et al. (1997) and Johnston and Wells (2020).

11. See Porter (1998).

12. These are the subjects that form a business ecosystem.

13. See He et al. (2014).

14. See Perez (2002).

15. See Haynes (2008).

16. See Taylor (1981).

17. See Tonnelly (2019).

18. Jardine Motors Group (2021) blog.

19. See Carr (1993).

20. See Donnelly and Thoms (1989).

21. See Haynes (2008).

22. See Berg (1985).

23. See Kirby (1999).

24. See Zeitlin (2000).

25. Gibbs (2013).

26. See Catalan Vidal (2017).

27. Perez (2002).

28. See Flynn and Taylor (1986).

29. See Law (1985).

30. See Zeitlin (2000).

31. Ibid.

32. See Taylor (1981).

33. Ibid.

34. See Nuttall et al. (2011).

35. See Pardi (2010).

36. IfM research report.

37. See Turnbull et al. (1992).

38. Ibid.

39. See Larsson (2002).

40. See Rhodes (2020).

41. Inflation in the UK was through the roof (equal to $17.99 \%$ in 1980 ) and so was the unemployment rate (equal to 11.5 in 1983).

42. See Imrie (1991).

43. An average of around less 2500 semi-skilled workers (Imrie, 1991).

44. See Collins and Harris (1999).

45. See Taylor (1981).

46. See Turnbull et al. (1992).

47. See Turnbull (1988).
48. See Taylor and Wren (1997).

49. See Gudgin (1995).

50. Driver and Oughton (2008) found a strong positive correlation coefficient $(0.86)$ between innovation and investment in plant and machinery at the beginning of the 1990s, which meant that to an increase in investment in plant and machinery corresponded a significantly positive increase in innovation - or vice versa.

51. See Imrie (1991).

52. See Janni and Farschi (2009).

53. See Leech and McCullie (2016).

54. Ibid.

55. See Turner et al. (2020).

56. See Nunes and Bennett (2010).

57. See Farshchi and Janne (2003).

58. See Bailey and MacNeill (2008) and Jarvis et al. (2012).

59. See Jarvis et al. (2012).

60. See Bailey and MacNeill (2008).

61. See Parker-Rhodes (2012).

62. See OECD (2010).

63. See MacNeill and Bailey (2010).

64. See the West Midlands' ERDF Report (20072013).

65. Delteil and Kirov (2016).

66. Tchalakov and Burton (2001).

67. Op. cit.

68. See Rogers and Tchalakov (2014) and Tchalakov and Burton (2001).

69. See Boyanov (2014).

70. See interview with Ivan Popov at Nikula and Tchalakov (2014: 79-113) "Prof. Ivan N. Popov: the Founder Bulgarian Electronic Industry."

71. Nikula and Tchalakov (2014: 98).

72. Tactics: 217.

73. See Tchalakov and Burton (2001).

74. At the time referred as the Higher Institute of Mechanical and Electrical Engineering "V. I. Lenin."

75. See ARC Fund (2019: 101).

76. See Kirov (2001).

77. Op. cit.

78. Tchalakov and Burton (2001).

79. Makó et al. (2009).

80. Op. Cit. 
81. Surubaru (2020).

82. See ARC Fund (2019: 55).

83. Ibid.

84. See ARC Fund (2019: 61).

85. See Dimitrova and Buzogány (2014).

86. See Rydin et al. (2018).

\section{References}

Acs ZJ, Stam E, Audretsch DB, et al. (2017) The lineages of the entrepreneurial ecosystem approach. Small Business Economics 49(1): 1-10.

ARC Fund (2019) Innovations BG 2019. Sofia. Available at: http://www.arcfund.net/index.php? id=2060 (accessed 22 May 2021).

Bailey D and MacNeill S (2008) The rover task force: a case study in proactive and reactive policy intervention? Regional Science Policy \& Practice 1(1): 109-124.

Berg M (1985) Government policy and its impact on the motor industry. Long Range Planning 18(6): 40-47.

Berlin L (2003) Entrepreneurship and the rise of Silicon Valley: the career of Robert Noyce, 1956-1990. Enterprise \& Society 4(4): 586-591.

Bessant J, Kaplinsky R and Lamming R (2003) Putting supply chain learning into practice. International Journal of Operations \& Production Management 23(2): 167-184.

Boyanov K (2014) 'Brief information about the development of computer technology in Bulgaria' (Short Кратки сведения за развитието на изчислителната течника в БълГария). Annual of "Informatics" Section Union of Scientists in Bulgaria 7: 1-23.

Carr C (1993) Global, national and resource-based strategies: an examination of strategic choice and performance in the vehicle components industry. Strategic Management Journal 14(7): 551-567.

Catalan Vidal J (2017) The stagflation crisis and the European automotive industry, 1973-1985. Business History 59(1): 4-34.

Collins A and Harris RID (1999) Downsizing and productivity: the case of UK motor vehicle manufacturing 1974-1994. Managerial and Decision Economics 20(5): 281-290.
Cooke P, Uranga MG and Etxebarria G (1997) Regional innovation systems: institutional and organisational dimensions. Research Policy 26(45): 475-491.

Delteil V and Kirov VN (2016) (eds) Labour and Social Transformation in Central and Eastern Europe: Europeanization and Beyond. London: Routledge.

Dimitrova A and Buzogány A (2014) Post-accession policy-making in Bulgaria and Romania: can nonstate actors use EU rules to promote better governance? Journal of Common Market Studies 52(1): 139-156.

Donnelly T and Thoms D (1989) Trade unions, management and the search for production in the coventry motor car industry, 1939-1975. Business History 31(2): 98-113.

Economist Intelligence Unit (2014) Innovation Ecosystems Empowering Entrepreneurs and Powering Economies. London: EIU.

ERDF (2007) 'West Midlands European Regional Development Fund Programme, 2007-2013'. ERDF.

Farshchi MA and Janne OEM (2003) 'Industrial transformation in the West Midlands automotive cluster: international networks and cooperative behavior'. In: Conference proceedings: clusters, industrial districts and firms: the challenges of globalisation, Modena, Italy, 12-13 September 2003.

Flynn N and Taylor AP (1986) Inside the rust belt: an analysis of the decline of the West Midlands economy. 1: international and national economic conditions. Environment and Planning A: Economy and Space 18(7): 865-900.

Gibbs N (2013) 'Thatcher Saved UK Auto Industry with Bailout, Academic Says'. Automotive News Europe. Available at: https://europe.autonews.com/ article/20130409/ANE/130409890/thatcher-saveduk-auto-industry-with-bailout-academic-says (accessed 28 May 2021).

Griffin E (2010) A Short History of the British Industrial Revolution.London: Palgrave.

Gudgin G (1995) Regional problems and policy in the UK. Oxford Review of Economic Policy 11(2): $18-63$. 
Haynes M (2008) The Evolution of the Economy of the West Midlands 1700-2007. University Wolverhampton Business School.

Imrie R (1991) Industrial change and local economic fragmentation: the case of Stoke-on-Trent. Geoforum 22(4): 433-453.

Janne O and Farschi MA (2009) Knowledge spillovers and industrial transformation: the west Midlands and Saxony automotive clusters. In: Farschi MA, McCann P and Janne O (eds) Technological Change and Mature Industrial Regions: Firms, Knowledge and Policy. New Horizons in Regional Science. Cheltenham, UK: Edward Elgar, 227-233.

Jardine Motors Group (2021) Available at: https:// news.jardinemotors.co.uk/lifestyle/the-history-ofcar-technology (accessed 28 May 2021).

Jarvis D, Berkeley N and Donnelly T (2012) Capturing the economic benefits of a transformative shift to low carbon automobility: a case study of the West Midlands, UK. Local Economy 27(7): 692-704.

Johnston A and Wells P (2020) Assessing the role of universities in a place-based Industrial Strategy: evidence from the UK. Local Economy 35(4): 384-402.

Kirby MW (1999) Blackett in the 'White Heat' of the scientific revolution: industrial modernisation under the labour governments, 1964-1970. Journal of the Operational Research Society 50(10): 985-993.

Kirov V (2001) 'La privatisation des entreprises bulgares: de la contrainte exogène à l'adaptation locale'. Communisme 64: 143-166.

Larsson A (2002) The development and regional significance of the automotive industry: supplier parks in Western Europe. International Journal of Urban and Regional Research 26(4): $767-784$.

Law CM (1985) The geography of industrial rationalisation: the British motor car assembly industry, 1972-1982. Geography 70(1): 1-12.

Leech J and McCullie A (2016) The Digitalisation of the UK Automotive Industry. KPMG Report.

Makó C, Illéssy M, Csizmadia P, et al. (2009) Changes in Work in Transformation Economies - The Case of the New Member States. Leuven: HIVA.
Menzani T and Zamagni V (2010) Cooperative networks in the Italian Economy. Enterprise \& Society 11(1): 98-127.

Nikula J and Tchalakov I (2014) Innovations and Entrepreneurs in Socialist and Post-socialist Societies. Cambridge Scholars Publishing.

Nunes B and Bennett D (2010) Green operations initiatives in the automotive industry: an environmental reports analysis and benchmarking study. Benchmarking: An International Journal 17(3): 396-420.

Nuttall WJ, Holweg M and Leybovich ME (2011) Too big to fail - Lessons for today and the future from British industrial policy, 1960-1990. Technological Forecasting and Social Change 78(8): 1286-1298.

OECD (2010) The Automobile Industry in and Beyond the Crisis in OECD Economic Outlook. Paris: OECD Publishing, Vol. 2009.

Pardi T (2010) Do State and Politics Matter? The case of Nissan's direct investment in Great Britain and its implications for British Leyland. Business \& Economic History On-Line 8.

Parker-Rhodes L (2012) 'Regional Innovation Report (West Midlands)' to the European Commission. Technopolis Group.

Perez C (2019) 'Transitioning to smart green growth: lessons from history'. In: Fouquet R (ed) Handbook on Green Growth. Cheltenham: Elgar, $447-463$.

Perez C (2002) Technological Revolutions and Financial Capital: The Dynamics of Bubbles and Golden Ages. Cheltenham: Edward Elgar Publishing.

Porter ME (1998) On Competition. Boston: Harvard Business School Press.

Rhodes C (2020) Manufacturing: Statistics and Policy. House of Commons Library 1942.

Rogers JD and Tchalakov I (2014) Computer networks as the embodiment of social networks: the role of national scientific communities in the development of internet in the US and Bulgaria. International Journal of Actor-Network Theory and Technological Innovation 6(3): 1-25.

Rydin Y, Natarajan L, Lee M, et al. (2018) Do local economic interests matter when regulating nationally significant infrastructure? The case of 
renewable energy infrastructure projects. Local Economy 33(3): 269-286.

Schorman R (2010) "This Astounding Car for $\$ 1,500$ ": the year automobile advertising came of age. Enterprise \& Society 11(3): 468-523.

Schumpeter JA (1976) Capitalism, Socialism and Democracy. London: Routledge.

Spigel B, Kitagawa F and Mason C (2020) A manifesto for researching entrepreneurial ecosystems. Local Economy 35(5): 482-495.

Stam FC and Spigel B (2016) Entrepreneurial ecosystems. USE Discussion Paper Series 16(13).

Surubaru NC (2020) 'European funds in Central and Eastern Europe: drivers of change or mere funding transfers? Evaluating the impact of European aid on national and local development in Bulgaria and Romania'. European Politics and Society 22: 1-19.

Taylor S (1981) De-industrialisation and unemployment in the West Midlands. The Political Quarterly 52(1): 64-73.

Taylor J and Wren C (1997) UK regional policy: an evaluation. Regional Studies 31(9): 835-848.

Tchalakov I and Burton P (eds) (2001) Project TACTICS, Telematics and Advanced Communications Industrial Comparative Study for Bulgaria, Romania and Macedonia. Final Report Prepared for the European Commission. Sofia: LIK, 376.
Turnbull PJ (1988) The limits to 'Japanisation'? Justin-Time, labour relations and the UK automotive industry. New Technology, Work and Employment 3(1): 7-20.

Turnbull P, Oliver N and Wilkinson B (1992) Buyersupplier relations in the UK - automotive industry: strategic implications of the Japanese manufacturing model. Strategic Management Journal 13(2): 159-168.

Turner C, Di Tommaso MR, Pollio C, et al. (2020) Who will win the electric vehicle race? The role of place-based assets and policy. Local Economy 35(4): 337-362.

Uyarra E and Flanagan K (2016) Revisiting the role of policy in regional innovation systems. In: Shearmu R, Carrincazeaux C and Doloreux D (eds) Handbook on the Geographies of Innovation. Cheltenham: Edward Elgar Publishing, 309-321.

Williamson PJ and De Meyer A (2012) Ecosystem advantage: how to successfully harness the power of partners. California Management Review 55(1): 24-46.

Zeitlin J (2000) Reconciling automation and flexibility? Technology and production in the postwar British motor vehicle industry. Enterprise \& Society 1(1): 9-62. 